\title{
Gammel Testamente ved Det Teologiske Fakultet ved Aarhus Universitet ${ }^{1}$
}

\author{
HANS J. LUNDAGER JENSEN
}

Jeg går ud, at tiltrædelsesforelæsningens raison d'être må være den passende lejlighed til at præsentere en person, der indtager en ny stilling, og at vedkommende i den forbindelse redegør for, hvordan han eller hun betragter tingenes tilstand inden for det fagområde, som stillingen vedrører, og udstikker nogle sigtepunkter for, hvordan han eller hun tænker sig, at stillingen kan bruges til gavn for dette fagområde. En sådan genre giver god mening i et system, der kendes fra store lande og store sprogområder, hvor personer har en karrieregang, der løber igennem forskellige institutioner, og hvor den pågældende vil være ukendt for de fleste af dem, der befolker den institution, hvor de betræder en stilling. Det passer dårligt for mit tilfælde; jeg kommer ikke et andet sted fra, jeg er ikke et ubeskrevet blad ved Det Teologiske Fakultet ved Aarhus Universitet, og at jeg tiltræeder et professorat i Det Gamle Testamente er ikke for mit vedkommende et rigtigt karriereskrift.

Fagets hidtidige professor, Kirsten Nielsen, ønskede at gå på pension pr. 1. februar 2009. I betragtning af fakultetets aktuelle situation, økonomisk, bemandingsmæssigt og fagligt, kunne det være en praktisk ordning, at professoratet i Gammel Testamente varetages af en allerede ansat med professorkvalifikationer. Mit fagområde er som bekendt Gammel Testamente, og derfor har jeg fra 1. februar fået overdraget det nu ledige professorat, som jeg vil varetage sideløbende med min hidtidige funktion. Rent praktisk indebærer det, at min undervisningstid deles ligeligt mellem uddannelserne i teologi og i religionsvidenskab; desuden vil jeg varetage de særlige professoratsforpligtelser, som særligt angår det gammeltestamentlige fagområde.

Jeg tror i øvrigt, at en ordning, der som denne kombinerer forsknings- og undervisningsopgaver inden for såvel det teologiske som det religionsvidenskabelige område, heller ikke er specielt akavet for netop dette fakultet. Det er ikke fremmed for Det

1 Tiltrædelsesforelæsning ved Aarhus Universitet, 26. februar 2009. 
Teologiske Fakultet ved Aarhus Universitet at betragte det som en styrke og en gevinst, at vores fakultet er et hus med mere end ét rum, og at der er åbne døre imellem rummene. Arabiskfaget har nu taget en naturlig drejning i retning af at fremhæve islamområdet som en central del, dvs. er blevet tonet mere i religionsvidenskabelig retning og har dermed også fået understreget sit faglige interessefællesskab med teologien. Klassisk teologiske områder som Bibelfag, Kristendommens historie og dens nutidige tilstand og etik og religionsfilosofi har en fremtrædende plads i religionsvidenskaben. Områder, metoder og teorier såsom sociologi, psykologi og antropologi, der er blevet dyrket særligt intensivt i religionsvidenskaben, inspirerer nogle teologiske kolleger eller indgår simpelthen som ligeberettigede dele af et teologisk curriculum. Det er givetvis ikke irrelevant samtidig at opretholde særlige fagidentiteter. En teologisk habitus kan og bør fortsat være anderledes end en religionsvidenskabelig eller en arabiskfaglig. Men en habitus opretholdes ikke bedst negativt ved at afskærme sig; den opretholdes og udvikler sig bedst ved at opdyrke det, der positivt definerer dens særlige tyngdepunkter og faglige mål. I det teologiske fakultets hus er mulighederne til stede for at belære hinanden og tage ved lære af hinanden. Og på dette punkt står det gammeltestamentlige fagområde i en privilegeret position.

Jeg vil gerne anvende forelæsningen her til at udtale om mig en række punkter, der har med det gammeltestamentlige fag at gøre, sådan som jeg ser det. Jeg udtaler mig som den person, der besætter (hvis det ord er det rigtige) professoratet i GT; men et professorat medfører ingen speciel myndighed. Også som professor er man i det danske undervisningssystem sig selv og kun sig selv, i langt de fleste spørgsmål sideordnet med sine kolleger inden for faget. Man har i udgangspunktet ingen specielle forskningsmidler til rådighed, man kan ikke ansætte en personlig assistent, man kan ikke dekretere en speciel faglig profil eller fremmane en særlig faglig ånd, der tiltænkes at regere på ens afdeling eller underafdeling. Sådan er systemet, og det har min opbakning. Sådan var det også, da jeg var fagets yngstemand som kandidatstipendiat og yngste lektor i 1980'erne, da Benedikt Otzen var fagets professor. Jeg oplevede en udstrakt grad af rummelighed og accept fra ham og fra fagets andre ansatte, Hans Gottlieb, Knud Jeppesen, Bent Rosendal, Kirsten Nielsen og Niels Peter Lemche. Det var næppe alt af det, jeg dengang var interesseret i, der forekom alle mine ældre kolleger lige relevant for det gammeltestamentlige fag; men jeg har aldrig oplevet, at nogle forsøgte at rette mig ind efter en bestemt skole, pålægge mig at forske i bestemte emner eller følge bestemte teorier eller metoder.

Jeg kan derfor ikke forudse, hvilke retninger GT-faget vil tage her i Århus. Men jeg kan godt give mit bud på fagets aktuelle situation som forskningsområde. Som sagt er GT-faget i en favorabel position i et hus, der rummer såvel teologi som religionsvidenskab. GT-faget er født som en del af den teologiske fagvifte, og dens plads her er igen bestemt af GT som en del af de kristne kirkesamfunds kanoniske tekstsamling. Men GT-faget har i mange perioder af sin historie engageret sig positivt med tilgrænsende videnskaber i gensidig udveksling. Uden tvivl har faget mest været den modtagende part. Selv om det med flere faste stillinger ved flere universiteter i Danmark 
kan siges ikke at være så ilde stedt endda - fx målt i forhold til hvordan forsknings- og undervisningssituationen er for adskillige af denne verdens religioner, hvis tilhængerantal og historiske tyngde betragtelig overgår det gammeltestamentlige - er det dog et lille område $\mathrm{i}$ forhold til de videnskabelige traditioner og miljøer, som det igennem sin historie har været i kontakt med. En del af denne historie, sådan som jeg selv ser den, vil jeg gerne her ridse op i al korthed. Jeg vil ikke give en dækkende beskrivelse af de skift i trends, som GT-faget har været underkastet de sidste 30-40 år, dels fordi tiden ikke tillader det, dels fordi Kirsten Nielsen i sin afskedsforelæsning ved begyndelsen af forårssemesteret var inde på de samme emner, og dér gav en oversigt, jeg kan tilslutte mig. ${ }^{2}$ Kirsten Nielsen fokuserede på den litterære vending, som en stor del af det gammeltestamentlige fag tog 1980'erne. Jeg vil her anlægge en lidt anden vinkel. Jeg vil relatere nogle vigtige tendenser i den gammeltestamentlige forsknings historie til åndshistoriske og humanvidenskabelige strømninger. Jeg vil koncentrere mig om dem, der i særlig grad har haft betydning for min andel af den gammeltestamentlige forskning og undervisning, der drives her ved fakultetet.

\section{GT-fagets fundering i romantisk oplysning}

GT-faget fødes i 1700-tallet i erkendelsen af, at den gammeltestamentlige verden var en anden end den nytestamentlige. Den kristne kirkes kanons to dele er udtryk for to mentale universer. Og mens den nytestamentlige ikke kan tænkes uafhængigt af den gammeltestamentlige, fordi GT er NTs historiske forudsætning og stadige reference, kan den gammeltestamentlige nemt tænkes uafhængigt af den nytestamentlige. Det mest markante udslag af denne erkendelse af det gammeltestamentliges sui-generiskarakter, dets selvstændighed, er formentlig den tyske filosof Johann Gottfried Herders bog Vom Geiste der ebräischen Poesie (1782-83). Herder er god at begynde med - ikke fordi hans bog var typisk for den gammeltestamentlige akademiske videnskab, der var ved at danne sig, men fordi det grundlæggende i hans tilgang fortsat er bæredygtigt. Det var Herder og den romantiske oplysning (og NB: ikke romantik i modsætning til oplysning), der indførte forståelsen for, at menneskelige fællesskaber består ikke mindst i form af og i kraft af partikulære symbolske rum med interne valg og spilleregler, altså det som vi i vore dage almindeligvis forstår ved 'kulturer'. ${ }^{3}$ Begrebet 'kultur' er ikke uproblematisk, og det er pt. også under delvis polemisk beskydning, ikke mindst, formentlig, som resultat af en overdreven vulgarisering og politisering. Men det rationelle i kulturbegrebet er efter min mening ubestrideligt, og erkendelsen af fænomenet

2 Jf. Kirsten Nielsen, "Gammel Testamente - lad faget leve, vokse og blomstre", Årsskrift 2009, Det Teologiske Fakultet, 24-28.

3 Herder kan derfor betragtes som en vigtig kilde til moderne sociologi og antropologi (John H. Zammito Kant, Herder, and the birth of Anthropology, The University of Chicago Press, Chicago 2002, 344f ; Forster "Johann Gottfried von Herder", Stanford Encyclopedia of Philosophy 2007: http://plato.stanford.edu/ entries/herder/ (set 2.6.2009). 
'kulturer' som en flerhed af størrelser er særlig relevant for GT-faget. Det er også den erkendelse, der ligeledes voksede ud af den romantiske oplysning, erkendelsen af menneskelige kulturers historiskhed, at de er særlige og begrænsede dannelser ikke kun i rum, men også i tid.

Den Herderske oplysning var tæt forbundet med den interesse for folkeminder eller folklore, bl.a. eventyr og folkeviser, der dukkede op i 1700-tallet, og for mytologi. Disse områder, mytologi og folkloristik, skulle få en afgørende betydning for GT-faget ca. 100 år senere, dvs. i årtierne op til første verdenskrig, for der var ud over alle andre mulige fælles områder ét punkt, der gjorde en forbindelse nærliggende. Folkloristik og mytologi vedrører anonyme betydningsdannelser: fortællinger og digte uden kendte forfattere, uden at man kan indplacere dem i tid og rum. Imidlertid gjaldt den mest markante forskning i GT i det meste af 1800-tallet den skrevne tekst. De mange semantiske inkonsistenser og logiske brud i de gammeltestamentlige tekster har været kendt siden oldtiden. De formelig inviterer til kritiske analyser af deres genealogi, og jødiske og de kristne fortolkningstraditioner har været kreative på dette punkt igennem århundrederne. Den forskningsretning, der fokuserede på den skrevne tekst og dens uimodsigelige heterogenitet, er den, der med en betegnelse, der lægger op til misforståelser, blev kendt som 'litterærkritik'. Det er litterærkritikken, der har givet os begreberne om et Præsteskrift, en Jahvist, en proto- og en deutero-Esajas, deuteronomistiske redaktioner af profetskrifter osv. Litterærkritikken er ofte blevet misforstået sådan, at dens væsentligste indhold skulle være at bestemme de forskellige litterære snit kronologisk i forhold til hinanden og i forhold til en ekstern begivenhedshistorie. Vanskelighederne ved det sidste har vist sig at være ganske betragtelige. Oprindeligt antog man, at det litterære lag i Genesis, som vi kender som Præsteskriftet, var det ældste, og at det Jahvistiske materiale skulle være et senere tilkommende supplement. Så var flertallet af forskere i mange år enige om, at det forholdt sig omvendt, at Jahvisten skulle gå tilbage til Salomo og en særlig jernalder-oplysning af en slags, og det videregav man så til de teologiske studerende. $\mathrm{Nu}$ er man formentlig vendt tilbage til noget, der ligner den oprindelige forestilling. Under alle omstændigheder bidrager sådanne ture rundt i hypotesedannelsernes mølle ikke til at skaffe et fagområde respekt eller entusiasme. Dertil kommer, at litterærkritikken har fået ry for at være en steril og pedantisk tilgang, hvis udbytte ikke stod i noget fornuftigt forhold til indsatsen. Det sidste kan der bestemt være meget om. Der kan gå meget tid med pindehuggeri om halve og kvarte vers. Det er blot irrelevant som akademisk og videnskabelig kritik. Videnskab ser ofte på meget små enheder, som bekendt.

\section{Litterærkritik og Bibelkritik}

Jeg vil grundlæggende forsvare litterærkritikken som en fortsat relevant eksegetisk dimension, i det mindste i det, som jeg opfatter som dens rationelle og uopgivelige kerne. Det essentielle ved litterærkritikken er ikke dateringer af tekstlag, også selv om 
den nok så mange gange er blevet legitimeret ved dette formål. Det essentielle er selve iagttagelsen af logiske brud i tekstoverfladen, iagttagelsen af teksternes fragmentation, og forsøget på at samle stumperne til nogenlunde konsistente helheder. Relevansen heri består i to lige centrale ting for GT-faget: dels selve erkendelsen af tekstens historicitet, dels perspektiverne $i$, at de mindre helheder kan danne tematisk konsistente tekstuniverser. Det første af disse to punkter: erkendelsen af tekstens historicitet, har ganske vist været betragtet som en trivialitet i mange år. Jeg har selv hørt til dem, der har ment, at vi ikke i uddannelsessammenhænge behøvede at bruge alt for meget krudt på det. Men 'triviel' er jo ikke det samme som fejlagtigt. Noget er i en konkret samtalesituation trivielt, hvis de, man taler med, ved dette noget lige så godt som en selv. Det kan vi stadigvæk ikke regne med gælder om Bibeltekstens heterogenitet og historicitet. Og måske begynder teologien som kritisk, universitetsbaseret videnskab netop her: i erkendelsen af, den hellige tekst er nedskrevet af forskellige mennesker med forskellige dagsordener. Uanset hvor triviel denne erkendelse måtte være i de teologiske fagmiljøer, er det, at den er en velkendt og accepteret sag blandt teologer, fortsat ikke trivielt for en større offentlighed; og den er slet ikke triviel, hvis man foretager en punkt-for-punkt-sammenligning med den største religiøse udfordring for de kristne trossamfund i vores generation, nemlig islam. En kritisk Koran-forskning, der kan levere det, som den kritiske GT-forskning har kunnet yde, er fortsat kun i sin vorden. Den anden lære af litterærkritikken, at tekstens dele kan tilhøre relativt konsistente tekstuniverser, er efter min mening forudsætningen for, at GT-faget kan levere en gammeltestamentlig teologi. Jeg vil komme tilbage til dette punkt.

\section{Formkritik og folklore}

Først vil jeg tage tråden op fra Herder. Indflydelsen fra den romantiske oplysnings opdagelse af og interesse for folkeligt-anonyme fortællinger slår formentlig først rigtig igennem med den forskningsretning, der gerne kaldes 'formhistorie' eller bedre 'formkritik'. Den er med al ret forbundet med Hermann Gunkels navn og hans kommentar til Genesis, der kom i første udgave i 1901. Gunkels formkritik var grundlæggende et hermeneutisk greb, der ved at klarlægge betydningen af sproglige genrer og disses forbundethed med bestemte sociale situationer ville løfte Bibelens fortællinger ud af et umuligt dilemma mellem historisk sandhed og historisk løgn og over i en anden fornuftsform, det poetiske eller det æstetiske. For Genesis' vedkommende skete dette i praksis, ved at Gunkel placerede den farverige mangfoldighed af fortællinger om forbudt frugt, talende slanger, syndflod osv. dels ind i en nærorientalsk kontekst, hvor navnlig den nyopdukkede mesopotamiske kultur blev afgørende for forståelsen af GT, dels ind i en universel kontekst af myter, sagn, legender og eventyr. Gunkels kommentar myldrer med paralleller fra eskimoer til babyloniere. Dette var typisk for tiden. Folkloristik var en vital videnskab i 1800-tallet - man kan blot tænke på navne som brødrene Grimm og Wilhelm Mannhardt i Tyskland eller Svend Grundtvig og Axel 
Olrik i Danmark, og i USA, måske som det vigtigste tiltag, Franz Boas og hans skoles minutiøse kortlægning af de nordamerikanske Nordvestkystkulturer. Det var givetvis ikke en tilfældighed, at Boas var tysk-amerikaner, og forbindelsen fra det Herderske anslag til den amerikanske feltarbejdetradition og den amerikanske kulturantropologi, inklusive såvel en Clifford Geertz som nutidens cultural studies er vistnok generelt anerkendt. Med Gunkel indskrives også en vigtig del af den gammeltestamentlige forskning i denne tradition. Slutningen af 1800-tallet og tiden op til første verdenskrig var i det hele taget en umådelig rig periode i europæisk og nordamerikansk tænkning; og hvis Friedrich Nietzsche og Sigmund Freud måske nok er så rigeligt tilegnet, har vi formentlig endnu ikke gjort os færdige med ansatserne hos en James Georges Frazer eller en Emile Durkheim. For det gammeltestamentlige områdes vedkommende er det bemærkelsesværdigt, at det på samme tid og uproblematisk kunne høre til to fagtraditioner: den teologiske Bibeleksegese på den ene side, naturligvis, og den nyopdukkede religionshistorie og religionsvidenskab (betegnelsen blev brugt også dengang) på den anden side. Robertson Smith i det britiske og Julius Wellhausen i det tyske var religionsvidenskabsfolk lige så meget som de var eksegeter. I sin oversigt over religionsforskningens ældre historie, Thinking about religion, har Ivan Strenski med rette også fremhævet denne fælles oprindelse og formuleret ønsket om at bringe dem sammen igen. ${ }^{4}$

\section{Kulturelle indsnævringer}

Forbindelsen mellem religionsvidenskaben og Bibelvidenskaberne gik tabt i tiden efter første verdenskrig. Begge trak sig ind i kulturspecifikke skaller. Årsagerne var ganske vist forskellige, men virkningerne sammenlignelige, og man kan formode, at nogle fælles, strukturelle forhold har været udslagsgivende. Den førende religionsvidenskab blev først funktionalistisk eller struktur-funktionalistisk, senere social- eller kulturantropologisk, og den koncentrerede sig i alle udgaver om enkeltkulturer i disses synkrone tilstande og deres interne sammenhænge. GT-faget, navnlig i dens internationalt førende udgave, dvs. i den tysk-protestantiske udgave med navne som Alt, Noth og von Rad, fokuserede på Israels historie og de gammeltestamentlige tekster som kilder til Israels religionshistorie; forbindelser og paralleller blev kun vurderet som relevante, hvis der kunne hævdes oplagte historiske kontinuiteter. Det Gamle Testamentes omverden omfattede ikke længere eskimoer og bantufolk, men blev indskrænket til Ugarit, med udblik til andre dele an den nære Orient. Den skandinaviske skole, med navne som Johannes Pedersen og Sigmund Mowinckel, havde nok et større blik for betydningen af fundamentale religiøse fænomener som kult og ritual; men også deres religiøse materiale var GT og dets nærmeste naboer i tid og rum. Uanset de resultater, der

4 Ivan Stenski, Thinking about Religion. An Historical Introduction to Theories of Religion, Blackwell, Oxford 2006, 341f. 
i øvrigt blev opnået ad denne vej, fortonede der sig dermed dét perspektiv, der var så tydeligt hos Gunkel: at Det Gamle Testamente tilhører mindst tre riger samtidig, og at dette tredobbelte tilhørsforhold er en særlig værdifuld dimension. GT det tilhører for det første den bibelsk-kristne tradition som en del af dennes kanon. For det andet tilhører det sin egen historisk-kulturelle verden, der også omfatter de talrige og tætte forbindelser til den nærorientalske og, må man tilføje, den mediterrane kontekst. Og for det tredje tilhører den en menneskehedsverden af forestillinger, fortællinger og ritualer. Det sidste punkt kan også have teologiske implikationer.

\section{Eksegese og strukturalisme}

Sig mig, hvem dine helte er, og jeg skal sige dig, hvem du er. Med Gunkels navn har jeg allerede nævnt en af mine egne helte. Jeg vil ikke her nævne dem alle. Men jeg vil nævne Claus Westermann, også han forfatter af en mægtig Genesiskommentar i serien Biblischer Kommentar Altes Testament. Mens indplaceringen af Genesis' og Det Gamle Testamentes fortælleverden i et bred antropologisk kontekst var forventelig på Gunkels tid, var det usædvanligt, at Westermanns kommentar fra 1960'erne gjorde det samme, om end i mindre målestok. Det er en af grundene til, at jeg betragter hans gammeltestamentlige teologi ${ }^{5}$ som den mest interessante af de mange, der blev skrevet af generationen efter Gerhard von Rad. I sin villighed til at anlægge et komparativt blik ud over den nærorientalske verden var Westermann dengang en undtagelse fra det kulturisolerende paradigme. I hans Genesis-kommentar antydes en første kontakt mellem det gammeltestamentlige felt og en af de strømninger i religionsvidenskaben, der gik imod det kulturisolerende paradigme, nemlig den franske strukturalisme. To yderligere af mine mange helte, George Dumézil og derefter Claude Lévi-Strauss, insisterede i midten af det 20. årh. på ikke at se på enkeltkulturer isoleret, men betragte dem, eller nærmere bestemt deres mentale konstruktioner, deres myter, forestillinger osv., som lokale nedslag i tid og rum af overkulturelle skemaer. If. denne tankegang kunne man kun forstå noget, fx en myte eller et ritual, hvis man betragtede det som en særlig konstellation, der eks- eller implicit var en variation af noget andet, noget der gik forud, eller noget, der var til stede samtidig, men som et alternativ. I mere nutidige termer kan man formentlig her tale om selektion og adaption. De overkulturelle skemaer foreligger ikke empirisk; de skal rekonstrueres som modeller. Men det er her, videnskaben begynder. Hos Dumézil var skemaerne ganske vist forstået som en specifik kulturel arv, relevant for en familie af kulturer. Først hos Lévi-Strauss åbnes der for det perspektiv, at skemaerne hviler på strukturer, der ikke er kulturspecifikke, men som tilhører menneskeheden som art, nærmere bestemt dens generelle kognitive udrustning

5 Claus Westermann, Die Theologie des Alten Testaments in Grundzügen, Das Alte Testament Deutsch, Vandenhoeck \& Ruprecht, Göttingen 1978. 
i hjernebarken. Den Lévi-strausske strukturalisme indvarslede vore dages kognitive gennembrud.

I mit eget arbejde har jeg ment at følge denne tråd. Hvis Det Gamle Testamentes fortællinger og forestillinger på den ene side med større eller mindre ret kan betragtes som en kulturel verden sui generis - med samme ret som egyptisk, mesopotamisk etc. kan betragtes som sådanne sui generis-verdener (og jeg er klar over, at der her kan rejse sig et bjerg af problemer) - kan den på den anden side forstås som en variation over generelle, humane muligheder for at skabe betydning. I så fald kan en given fortælling, fx, for at tage det mest nærliggende eksempel af alle, fortællingen om Edens have, tænkes at være kommet i stand som en specifik variation af andre mentale konstruktioner i form af myter, legender, ritualer, inden for og uden for Det Gamle Testamente. Jeg mener således at have givet en plausibel argumentation for, at tematikken i Genesis' urhistorie er sagligt forbundet med andre mentale universer såvel inden som uden for Det Gamle Testamente. Det giver god mening at se fortællingen om Edens have som en transformation af den præstelige teologis grundscenarie, offerkulten i ørkenvandringens tabernakel; hvad den ene beskriver som natur, fugtigt, nøgent, barnligt og som en fortælling om en adskillelse af to parter, det guddommelige og det menneskelige, som egentlig burde have været sammen, beskriver den anden som kultur, tørt, påklædt, voksent og som en fortælling om fastholdelsen af en forbindelse mellem det guddommelige og det menneskelige, som egentlig ikke burde kunne lade sig gøre. ${ }^{6}$ Men tilsvarende giver det også god mening at antage, at fortællingen om Edens have var en slags israelitisk pendant til den myte, som Lévi-Strauss i sine 'mytologikker' kom til at betragte som indbegrebet af amerikansk mytologi, den måske urgamle myte om fugleredeplyndreren og ildens erobring. ${ }^{7}$ For begge handler om kulturens oprindelse ud af en menneskehedens barndom, hvor alting var tæt på hinanden, sol og jord, mennesker og jaguarer, og begge fortæller denne historie, der må høre til menneskehedens allerældste repertoire af historier, først og fremmest ved at fortælle den som historie om køkkenets oprindelse. Har man først indset, at offerkulten omkring tabernaklet er ét stort køkken, til glæde for både guddommens dyrkere og for guddommen selv, ser man, at strukturerne forbinder sig og noget i retning af et subkulturelt, humant tankesystem aftegner sig.

\section{Mentalitet og ontologi}

At rekonstruere sådanne forbindelser er også at kortlægge ikke kun eksplicitte forestillinger, men også implicitte. Forståelsen af Det Gamle Testamente er til dels en slags 'idehistorie', både når man undersøger konkrete skrifters eller tekststykkers temaer og

6 Hans J. Lundager Jensen, Den fortærende ild, Aarhus Universitetsforlag, Aarhus 2000, 342f.

7 Claude Lévi-Strauss, Le Cru et le cuit, Plon, Paris 1964, 43-45. 74-81, et passim. 
litterære tilblivelseshistorie, når man forsøger at rekonstruere 'Israels' religiøse historie, og når man forsøger at rekonstruere hovedtankerne i en gammeltestamentlig teologi. Idehistorien vil jeg her forstå analogt med teologihistorie; den angår de eksplicitte forestillinger og ræsonnementer. Men for at forstå disse er det nødvendigt også at rekonstruere det, der ikke siges eksplicit, eller kun lige netop antydes. Man kan måske tale om en kulturs 'ubevidste', hvis dette ord ikke tages i en meget dramatisk forstand som fx den Freudske, hvor det ubevidste er det fortrængte og traumatiske. Her vil jeg med 'ubevidst' forstå det, der mestendels tages for givet, det der siger sig selv og derfor ikke behøver at siges, eller, i det mindste i et samfund, hvor den blotte skriftliggørelse var en bekostelig affære for specialister, ikke var noget, der var nogen særlig grund til at fastholde i skrift. Nødvendigheden af at afdække det kulturelt ubevidste giver sig af den afstand i tid og rum, der adskiller os fra det gamle Israel, og som gør, at vi typisk er nødt til at interessere os for noget andet end det, teksterne har fastholdt i skriftens kunstige form for hukommelse.

Når vi i fortællingen i Gen 28 læser om patriarken Jakobs drøm i Betel, om englene på himmelstigen og indretningen af et helligsted for Jahve, vil fortællingen tydeligvis fortælle os, at denne person, Jakob, søn af Isak, så dette syn og at det var her, netop i Betel, at der skulle være et helligsted. Men for os i vore dage vil disse oplysninger typisk være af relativ mindre interesse. Om helligstedet skulle ligge i Betel eller et andet sted, om det var lige Jakob eller en anden, der havde dette syn, forekommer i hvert fald mig og, antager jeg, de fleste nutidige mennesker, mindre interessant end det, som fortællingen stiltiende forudsætter, fordi den ikke behøver at argumentere for det: selve det forhold, at der er engle, at Jahve bør have et helligsted, eller at Jahve nok klart nok er en guddom, men at det for Jakob ikke umiddelbart er indlysende, hoilken guddom han er, at dømme ud fra Jahves første replik: "Jeg er Jahve, din fader Abrahams og Isaks gud." Her møder vi sporene efter en mental verden, der ikke er moderne, sekulariserede menneskers, en verden hvor det nok er interessant, at der er engle og guder (interessant nok til at fortælle om det!), men at det er mere interessant og kontroversielt, hoor det er, englene passerer mellem himmel og jord, hoilken guddom der hersker i dette land, og hvor guddommen ønsker et helligsted. Det er primært sådanne spørgsmål, Det Gamle Testamente svarer på. Man kan også betragte det kulturelt ubevidste som en slags scene eller baggrund for de temaer, der fremhæves i forgrunden. Den hermeneutiske afstand mellem teksterne og os gør, at forholdet mellem teksternes baggrund og deres forgrund vendes om: Vi må først spørge til, hvad teksterne overhovedet mener med engle, guddomme, helligsteder.

Det kulturelt ubevidste omtaler jeg selv undertiden som den implicitte 'ontologi' med en betegnelse, der nu engang er i omløb i antropologi og religionsvidenskab, selv om den sikkert ikke vil falde i strengere filosofisk skoledes smag. 'Ontologi' er der i denne forstand tale om, når det drejer sig om de grundlæggende forhold i verden, 'det, der findes' (altså fx guddomme, engle, helligsteder), inklusive, vil jeg antage, det der er mere og mindre godt, nyttigt, meningsfuldt, skønt. Betragter man sagen her som forestillinger, kan man tale om en gruppes kultur eller, som det hedder i en oprindelig 
fransk kontekst, mentalitet. At rekonstruere en gammeltestamentlig ontologi vil her være det samme som at drive gammeltestamentlig mentalitetshistorie. I sin nye bog om gammeltestamentlig teologi er Niels Peter Lemche inde på det samme forhold. ${ }^{8}$ Selv om han og jeg næppe er enige om, hvad der nærmere ligger, eller bør ligge, i betegnelsen 'mentalitetshistorie', (jeg mener, at min forståelse er tættere på det, man møder hos mestre som Braudel, Duby og le Goff), har også jeg fornemmelsen af, at gammeltestamentefaget her har noget at lære. I den middelalderkontekst, som den franske mentalitetshistorie primært har været anvendt, kan forholdet mellem idehistorie og mentalitetshistorie illustreres som de forestillinger, der var fælles for en Thomas Aquinas og en savoyardisk gedehyrde. Selv om de på alle måder var milevidt fra hinanden, når det kom til eksplicitte tankegange og forestillinger, tilhørte de også begge en kultur, hvor en lang række antagelser var implicitte, fordi de deltes af alle. Thomas kendte sin Aristoteles og tilhører bl.a. derfor idehistorien. Men han og gedehyrden tog for givet, at der fandtes dæmoner. ${ }^{9}$

\section{Gammeltestamentlig teologi}

Jeg er kommet ind på mentalitetshistoriens mulige relevans som inspirationskilde for den gammeltestamentlige forskning, fordi den peger frem mod det punkt, jeg gerne vil slutte denne forelæsning på, nemlig nogle betragtninger over emnet gammeltestamentlig teologi. I den faglige tradition indgår dette emne, eller dimension, som et særskilt anliggende i en vifte af underafdelinger, der også omfatter filologi, Palæstinas historie, Palæstinas arkæologi, religionshistorie, tekstkritik og teksthistorie, såvel som særlige empiriske områder som Ugarit-studier og Qumran-studier. I alle tilfælde er der tale om sub-discipliner, der rækker ind over andre, beslægtede discipliner. I filologien mødes gammeltestamentlige forskere med specialister inden for andre nærorientalske og mediterrane sprog, i arkæologien med specialister inden for nærorientalsk arkæologi osv. Alle er de områder, der kan have en forførende karakter, og som også i tidens løb har suget mere end én mulig gammeltestamenteforsker ind og ikke sluppet ham eller hende ud igen. I forhold til denne farverige mangfoldighed kan gammeltestamentlig teologi tænkes som det sted, hvis opgave det er at sammenfatte de grundlæggende forestillinger i Det Gamle Testamente om det guddommelige og verden, kort sagt sige, hvad det grundlæggende drejer sig om i Det Gamle Testamente. Meget ofte bliver muligheden for en sådan syntese imidlertid betvivlet. Det sker bl.a. i den bog af Niels Peter Lemche, som jeg lige har nævnt, og som synes at konkludere, at Det Gamle Testamentes heterogenitet og den dramatiske afstand mellem den fortalte historie og den reelle historie gør, at der ikke er en lære eller lignende, der kan sammenfattes og gen- 
gives i en syntese. Lemche anbefaler i stedet en bibelsk teologi, hvor det er grundtemaer i Det Ny Testamente, der skal afgøre de temaer i Det Gamle, der kan relevante for en teologi, der så til gengæld skal være ligefrem og uapologetisk kristen. En kritik, der er ofte er blevet anført, og som formentlig er parallel med Lemches, er, at en gammeltestamentlig teologi på sine egne, dvs. før- eller ikke-kristne præmisser, ikke er til at skelne fra en religionshistorie, og det antages at være en invaliderende kritik. Sådan ser jeg ikke på sagen.

Jeg kan ikke afvise den teologiske relevans af en specifik kristen bibelsk teologi. Men jeg vil være mere optimistisk med hensyn til muligheden for og relevansen af en særlig gammeltestamentlig teologi. Udgangspunktet, efter min mening, bør være det samme som for den gammeltestamentlige teksteksegese, nemlig teksternes umiddelbare historicitet og heterogenitet. Det er velkendt, at Det Gamle Testamente ikke er blevet til som noget, der tåler sammenligning med de flestes intuitive begreber om en 'bog', dvs. som en roman eller en lærebog. På én måde kan det være afklarende snarere at sammenligne den med en bog, der ikke er beregnet til at blive læst kontinuerligt, som fx telefonbogen. Men det kan også være øjenåbnende at sammenligne den med internet-leksikonet Wikipedia, der skrives af mange, anonyme, som skriver grundtekster og supplerer med afsnit og trækker fra og korrigerer stavning og årstal og retter kommaer, og hvis fælles anstrengelser resulterer i et værk, hvis egentlige forfatter er så tæt på Zeitgeisten, som man vel kan komme; og så kommer man igen Johan Gottfried Herder i hu, for det var vistnok ham, der oprindelig skabte ordet Zeitgeist. ${ }^{10}$

'Teologi' vil jeg i denne forbindelse tage i deskriptiv og historisk forstand, analogt til den måde, ordet 'teologi' bruges om fx egyptisk religions påstande om det guddommelige. Her kan man uden forbehold tale om teologier i flertal, efter hjemsted: Thebansk teologi, Memphis teologi, eller efter tidslig periode: Ahknatonisk, post-Ahknatonisk teologi. Hvis nogen skulle mene, at teologi dermed bliver til en slags religionshistorie - underforstået, at forehavendet dermed vil blive af mindre eller slet ingen teologisk relevans - vil jeg svare, at jeg forstår disse egyptiske teologier i analogi med Antiokensk og Alexandrinsk teologi, Augustins, Bernhards, Luthers, Calvins, Grundtvigs teologier, dvs. relativt sluttede og selvberoende tankekonstruktioner, der omfatter de fundamentale forhold inden for en given religion, hhv. en religiøs tradition. Disse teologier angiver hver deres vægtlægning af tematiske tyngdepunkter, og på hver sin måde selekterer og kombinerer de elementer ud fra en mere omfattende tradition.

Der er måske uoverstigelige vanskeligheder ved at skrive en samlende gammeltestamentlig teologi. Men i så fald er det af de samme grunde, som vil gøre det svært eller umuligt at skrive en kristen teologi. Det kan gøres normativt, dvs. selektivt og kombinatorisk, men ikke deskriptivt. Deskriptivt kan man måske skrive en Luthersk teologi. På samme måde kan gammeltestamentleren beskrive de teologier, der er $i$ Det Gamle Testamente, eller i det mindste de vigtigste af dem, såsom deuteronomistisk teologi, præstelig teologi, visdomsteologi, og formentlig andre, mindre, der er varian-

10 I hvert fald if. Wikipedia: http://de.wikipedia.org/wiki/Zeitgeist (set 25.2.2009). 
ter af en af hovedformerne, fx deuterojesajansk teologi som en variant af deuteronomistisk, eller Hellighedsloven som en kombination af præstelig og deuteronomistisk. En sådan beskrivelse kan imidlertid kun lade sig gøre, hvis man først accepterer litterærkritikkens basale belæring, der som sagt ikke er en datering af de gammeltestamentlige tekstlag, men den indledende sondring mellem tekstlagene overhovedet. Først derigennem kan man overhovedet se, at der er sådan noget som en særlig præsteskriftlig over for en særlig deuteronomistisk teologi. Uden denne sondring fremtræder Det Gamle Testamente primært som en samling af udsagn om Jahve som kriger og som konge og som fader osv. En beskrivelse af dem vil være en indsamling og notering af disse udsagn, ikke ulig oldtidens såkaldte listevidenskab, som vi har fx i Ordsprogenes bog. Men det er ved at se, ikke kun på hvad de forskellige tekstlag har selekteret til, men i samme omgang på, hvad de har selekteret fra, at deres respektive strukturer dukker op og begynder at antage relativt konsistente skikkelser. Kan man ikke sondre mellem det præstelige og det deuteronomistiske, kunne man ikke se, at hvor det deuteronomistiske, dvs. det mere velkendte, har modsætningen mellem israelitter og fremmedfolk, har præsterne modsætningen mellem præsterne og lægfolk. I andre koder optræder disse modsætninger som forholdet mellem, i den ene teologi, landet og udlandet og, i den anden, mellem templet og området udenfor, eller som dilemmaet mellem, om Jahve er en fjern guddom i himlen, der har efterladt sine dyrkere sin lov for at udfylde en ellers ubærlig afstand, eller om Jahve er en guddom, hvis nærhed er potentielt katastrofal, og som derfor har indstiftet et strengt ceremoniel, der skal sikre, at der bevares et minimum af afstand. Det er ved at observere disse systematiske forskelle, at vi også kan indse, at selv om de to teologiske systemer i deres foreliggende udformning synes at ligne hinanden - og måske skyldes dette også emsigt harmoniserende redaktorer - er de udtryk for forskellige prioriteringer, der potentielt modsiger hinanden. Den deuteronomistiske teologi har reelt ikke brug for templet, og præsterne har reelt ingen interesse $\mathrm{i}$ at skelne mellem israelitter og fremmedfolk.

At to teologier, der i så meget modsiger hinanden, kan rummes inden for samme religion, den jeg i anden sammenhæng har kaldt den gammeltestamentlige ${ }^{11}$, kalder på en afsluttende bemærkning. For det første er der intet usædvanligt i, at en religion kan rumme mere end én doktrin, også når det gælder det, der kunne formodes at høre til de mest centrale forestillinger. Det Gamle Testamente selv viser os igen og igen, at gensidigt udelukkende varianter kan accepteres. For det andet gives der formentlig et sæt af forestillinger, der udgør en art fælles grundstruktur, der udtrykkes på to så forskellige måder som dem, vi ser i hhv. den deuteronomistiske og den præstelige teologi. Dette hypotetiske sæt af forestillinger er just det kulturelt ubevidste, jeg omtalte tidligere, den fælles ontologi eller mentalitet, og som skal rekonstrueres, læses frem, fordi den ikke er direkte omsat til skrift. Denne grundlæggende ontologi er ikke fuldt kortlagt endnu, og jeg forudsiger ikke her et personligt forskningsprojekt. Men jeg vil alligevel som eksempel anføre, at selv om den deuteronomistiske og den præstelige

11 Hans J. Lundager Jensen, Gammeltestamentlig religion, Anis, København 1998. 
teologi synes at skille sig i meget væsentligt, set det ud til, at de begge er struktureret ud fra en fælles 'geometrisk' grundfigur med et centrum, der tendentielt nærmer sig det usynlige, og en periferi, der åbner sig ud i alle retninger og hvis grænser fortoner sig i det uendelige. Denne centrum-periferi-figur kan besættes med aktører, der kan være Jahve og menneskene, eller Jahve og hans dyrkere. Den kan besættes med templet og dagligdagen, eller med landet og de fremmede nationer. I en mental kode vil den være forholdet mellem toraen og de menneskelige bevidstheder, og i en særlig temporal vil den være forholdet mellem det uforanderlige og det periodiske. Denne særlige form for binaritet er $i k k e$ en dualisme, hvor to principper står fjendtligt over for hinanden. Hvad der er fælles for den præstelige og den deuteronomistiske teologi er ikke mindst just deres monistiske grundkarakter. Derfor er der i ingen af dem plads til en anti-guddom, og derfor er der ingen Djævel eller Satan i Det Gamle Testamente.

Selv om Det Gamle Testamente kan se ud som et rigeligt udforsket felt, er der altid noget at lave. Hvis der ikke gøres nye tekstfund fra den Nære Orient, så er der altid nye tendenser i de human- og samfundsvidenskaber, som er beslægtet med studiet af Det Gamle Testamente, som vi kan lære af, og hvor vi måske også, undertiden, kan lære fra os. En af de store trends i humanvidenskaberne i disse år er skrift og kollektiv hukommelse; man kan blot tænke på den opmærksomhed, der med rette er blevet egyptologen Jan Assmann til del. ${ }^{12}$ Men et sådant tema er perfekt for Det Gamle Testamente ved Det Teologiske Fakultet i Århus. Som Assmann i en fin analyse selv har gjort opmærksom på, er det i Deuteronomiums parænetiske afsnit, at man måske for første gang i den vestlige religionshistorie finder religiøse kilder, der selv understreger, at videreførelsen af deres fortællinger og forestillinger er selve kernen i en religion. ${ }^{13}$ En vigtig inspiration fra Assmann kom fra en af Durkheims elever (Maurice Halbwachs), ${ }^{14}$ og dermed mødes den centrale figur for moderne religionsvidenskab med det, der ofte (om end af andre og mindre gode grunde) er blevet betragtet som den centrale tekst $\mathrm{i}$ Det Gamle Testamente.

Der er mere at gøre, end vi kan klare her på fakultetet. Mine kolleger og jeg vil forfølge vores individuelle forskningsinteresser. Sammen vil vi bidrage til uddannelsen af teologistuderende på en måde, der vil forsøge både at fastholde det teologiske studiums og fags egenart og dets kontakt til de videnskaber, der er tættest beslægtet med den og som den altid har suget kraft og næring fra. Teologistudiets indhold og organisering står til debat i denne tid. Jeg vil personligt godt melde ud, at som professor i et fag inden for en større faglighed er der flere områder, jeg vil tage i betragtning. Jeg skal prøve at varetage GT-fagets interesser. Jeg er bevidst om, at dette er et blandt flere

12 Så meget, at der allerede i nogle år har været en modbevægelse: David Berliner, "The Abuses of Memory: Reflections on the Memory Boom in Anthropology", Anthropological Quarterly 78 (1), 197-211.

13 Jan Assmann, Religion und kulturelles Gedächtnis, Beck, München 2000, 28-34.

14 Assmanns ræsonnementer er reelt funderet i Durkheims religionssociologi, selv om dette ikke skinner igennem i hans tekster: Hans J. Lundager Jensen, "Religion, hukommelse og viden - Jan Assmann, med udblik til Durkheim, Rappaport og Augustin”, Religionsvidenskabeligt Tidsskrift 52, 2008, 3-17. 
nødvendige fag i en fagvifte, og det skal indgå på en fornuftig måde i denne større sammenhæng.

Hans J. Lundager Jensen, professor, dr.theol. Afdeling for Gammel og Ny Testamente, Aarhus Universitet Afdeling for Religionsvidenskab, Aarhus Universitet 